\title{
Sources and health risks of atmospheric particulate matter at Bhagwanpur, an industrial site along the Himalayan foothills
}

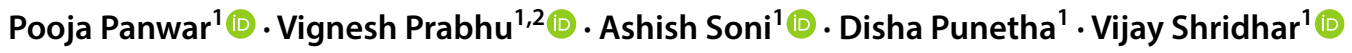

Received: 13 October 2019 / Accepted: 4 March 2020 / Published online: 12 March 2020

(c) Springer Nature Switzerland AG 2020

\begin{abstract}
Temporal variations in atmospheric particulate matter (PM) were studied in Bhagwanpur-a data-deficient area located along the foothills of the Himalayas. The concentrations of respirable suspended particulate matter (RSPM) and PM $\mathrm{P}_{0.4-10 \mu \mathrm{m}}$ (categorized into eight size fractions) were measured during winter and summer of 2014-2015. The RSPM concentration over a $24-\mathrm{h}$ period was found to be $259.6 \pm 52.6 \mu \mathrm{g} / \mathrm{m}^{3}$, which is 2.6 times greater than the permissible limit set by the Indian National Ambient Air Quality Standards. A significant difference ( $p<0.05, t$ test) in RSPM with seasons was observed with winter maximum $\left(284.6 \pm 48.6 \mu \mathrm{g} / \mathrm{m}^{3}\right)$ and summer minimum $\left(234.5 \pm 44.8 \mu \mathrm{g} / \mathrm{m}^{3}\right)$. Size fractionated PM measurements revealed maximum concentration $\left(36.4 \pm 5.2 \mu \mathrm{g} / \mathrm{m}^{3}\right)$ in $\mathrm{PM}_{9.0-10.0} \mu \mathrm{m}$, while least concentration was observed in $\mathrm{PM}_{2.1-3.3 \mu \mathrm{m}}\left(16.8 \pm 2.3 \mu \mathrm{g} / \mathrm{m}^{3}\right)$. Further, on quantification of 13 chemical species associated with RSPM, it was observed that mass concentration followed the trend of $\mathrm{Ca}>\mathrm{K}>\mathrm{Mg}>\mathrm{Al}>\mathrm{Zn}>\mathrm{Fe}>\mathrm{Mn}>\mathrm{Cr}>\mathrm{Co}>\mathrm{Ni}>\mathrm{Cu}>\mathrm{Pb}>\mathrm{C}$ $\mathrm{d}$. Source apportionment through principal component analysis revealed the sources such as industrial, vehicular, and crustal. The excess cancer risk for $\mathrm{Cr}$ was about 2.7 times higher than the tolerance level $\left(10^{-4}\right)$, while only $\mathrm{Pb}$ was below the safe limit $\left(10^{-6}\right)$. However, total ECR for $\mathrm{Cr}, \mathrm{Cd}, \mathrm{Pb}$, and $\mathrm{Ni}$ was about 3 times higher than the tolerance level. Three-day air mass back trajectory analysis reveals that emissions from biomass burning over the neighbouring regions adversely affect the air quality at the study site. The results of this study can be utilized toward the effective implementation of environmental regulations at the study site.
\end{abstract}

Keywords Particulate matter · Himalayas · Principal component analysis · Excess cancer risk · Back trajectory

\section{Introduction}

To improve the quality of life, developing countries are engaged in rapidly increasing the rate of urbanization and industrialization without properly managing industrial emissions [1]. In India, after the liberalization of the economy in the early 1990s, there has been a rapid increase in the rate of industrialization, especially in urban centers such as the National Capital Territory of Delhi, Bengaluru, Kanpur, Mumbai, Agra, and Hyderabad [2, 3]. Expectedly, developmental activities have increased the concentration of pollutants such as particulate matter (PM), carbon monoxide, and sulfur dioxide in the atmosphere $[4,5]$. This increase in particulate load in the atmosphere has led to numerous environmental and human health issues, not just in India but in entire South Asia.

Electronic supplementary material The online version of this article (https://doi.org/10.1007/s42452-020-2420-1) contains supplementary material, which is available to authorized users.

$\triangle$ Vijay Shridhar, vs@doonuniversity.ac.in; Pooja Panwar, ppanwar1@outlook.com; Vignesh Prabhu, vp88fri@gmail.com; Ashish Soni, absoni@live.com; Disha Punetha, punethadisha@gmail.com | ${ }^{1}$ Environmental Pollution Assessment Laboratory, School of Environment and Natural Resources, Doon University, Dehradun 248001, India. ${ }^{2}$ Center for Study of Science, Technology and Policy, Bengaluru 560094, India. 
In India, a number of studies have reported on the health risks associated with exposure to atmospheric $\mathrm{PM}_{1}$ (submicron particulates having aerodynamic diameter $\leq 1 \mu \mathrm{m}$ ), $\mathrm{PM}_{2.5}$ (fine particulates having aerodynamic diameter $\leq 2.5 \mu \mathrm{m}$ ), and $\mathrm{PM}_{10}$ (respirable particulates having aerodynamic diameter $\leq 10 \mu \mathrm{m}$ ) [6]. However, to fundamentally understand the adverse impact of atmospheric pollution on the human respiratory system, it is necessary to monitor the atmospheric PM in size fractions that can enter various parts of the respiratory system [7]. The human respiratory tract resembles an aerodynamic particle size classifying system that filters out particles as they progress deeper into the airway with air flow. Previously, Ny and Lee [8] used cascade impactors in Ulsan, South Korea, to measure atmospheric PM concentrations in the size fractions of $\mathrm{PM}_{<0.7 \mu \mathrm{m}}, \mathrm{PM}_{0.7-2.1 \mu \mathrm{m}}, \mathrm{PM}_{2.1-5.8 \mu \mathrm{m}}$, and $\mathrm{PM}_{5.8-10 \mu \mathrm{m}}$ that have the potential to enter the alveolar, bronchial, tracheobronchial, and extrathoracic regions, respectively.

PM comprises chemical species such as trace elements, ions, and organic compounds [9]. Owing to various anthropogenic activities, large quantities of these chemical species are emitted continuously into the atmosphere in the form of PM. Elements such as chromium ( $\mathrm{Cr}$ ) and cadmium (Cd) are emitted by the electroplating industry [10]; vanadium (V), copper (Cu), arsenic (As), and Cd by the metallurgical industry [11]; and zinc ( $\mathrm{Zn}$ ) by residual oil combustion [12]. Further, $\mathrm{Cu}, \mathrm{Zn}$, barium (Ba), antimony ( $\mathrm{Sb})$, lead $(\mathrm{Pb})$, manganese $(\mathrm{Mn})$, molybdenum (Mo), elemental carbon, organic carbon, and nickel (Ni) are widely used as vehicular source markers [13]. These chemical species have the potential to adversely affect human health. Calculating the Excess Cancer Risk (ECR) is the best practice to quantify the human carcinogenic risk posed by ambient $\mathrm{PM}$. In the Indian subcontinent, several researchers have estimated human carcinogenic risks through ECR calculation $[14,15]$. However, owing to large spatio-temporal variations in the chemical composition of PM, more studies are needed for data-deficient areas. In addition to assessing human health risks, source apportionment studies will help in formulating effective mitigation strategies for ambient PM. The Himalayas, in the north of India, constitute a pristine environment, and several studies have reported the influence of atmospheric aerosols emitted from the anthropogenic activities from the neighboring polluted regions [16-19]. However, detailed studies on particulate pollution from the industrialized areas in the proximity of the Himalayas are scarce.

The objectives of the present study are to (1) determine variations in the PM mass concentration in different size fractions, (2) examine the source apportionment of atmospheric respirable suspended particulate matter (RSPM), and (3) estimate the ECR because of exposure to toxic heavy metals associated with RSPM. Bhagwanpur, an emerging industrial hub in Uttarakhand, was selected to conduct this study because (1) Uttarakhand has a fragile ecosystem-representative of that of the Himalayas, and (2) Bhagwanpur is mostly a rural area. The latter criterion is important because most of the previous studies on this subject have been limited to urban sites.

\section{Materials and methods}

\subsection{Site description}

Bhagwanpur (lat: $29^{\circ} 58^{\prime} 12.35^{\prime \prime} \mathrm{N}$, long: $77^{\circ} 45^{\prime} 10.76^{\prime \prime} \mathrm{E}$, and altitude: $250 \mathrm{~m}$ above sea level), a mostly rural site in the Uttarakhand state located in the northern part of India, was chosen for this study (Fig. 1). It is an industrial hub surrounded by agricultural fields and residential areas. The average annual temperature and the total rainfall are about $28.9^{\circ} \mathrm{C}$ and $960 \mathrm{~mm}$, respectively. According to the 2011 census, the population in the study location was 7573. Bhagwanpur is situated along the New Delhi-Dehradun national highway, $197.5 \mathrm{~km}$ north of New Delhi. Various industries such as cement, brick, battery, electroplating, rubber, recycling, pharmaceutical, food, and packaging industries are located near the study area. The vehicular traffic count per hour for two-wheelers, threewheelers, light-duty vehicles, and heavy-duty vehicles was observed to be $170,44,337$, and 67 , respectively. The methodology used for measuring the vehicular traffic count is mentioned in supplementary text $\mathrm{S} 1$.

\subsection{Sampling and meteorological details}

An eight-stage non-viable Andersen Cascade Impactor (ACI) (Thermo Fischer Scientific, USA) was used for estimating the concentration of PM in the size range $0.4-10 \mu \mathrm{m}$ (Fig. S2). The sampler had the following aerodynamic cutoff diameters: 10-9.0 $\mu \mathrm{m}$ (Stage 1) (S1), 9.0-5.8 $\mu \mathrm{m}$ (Stage 2) (S2), 5.8-4.7 $\mu \mathrm{m}$ (Stage 3) (S3), 4.7-3.3 $\mu \mathrm{m}$ (Stage 4)

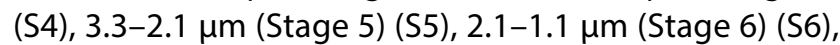
1.1-0.7 $\mu \mathrm{m}$ (Stage 7) (S7), and 0.7-0.4 $\mu \mathrm{m}$ (Stage 8) (S8). The combinations $(\mathrm{S} 6+\mathrm{S} 7+\mathrm{S} 8)$ and $(\mathrm{S} 1+\mathrm{S} 2+\mathrm{S} 3+\mathrm{S} 4+\mathrm{S} 5)$ represent the fine- and coarse-size fractions, respectively, of the PM. The flow rate of the instrument was set at 28.3 $\mathrm{L} / \mathrm{min}$, and the sampling duration was $24 \mathrm{~h}$, from 6:00 AM of first day to 6:00 AM of the next day, Indian Standard Time (IST).

A Respirable Dust Sampler (RDS) (model: SLERDS104NL, Spectro Lab, India) was used for estimating the RSPM concentration. Aerosol dust was collected using glass fiber filter paper (EPM 2000-Whatman, Size: $8^{\prime \prime} \times 10^{\prime \prime}$ ), and the concentration was measured gravimetrically. The 


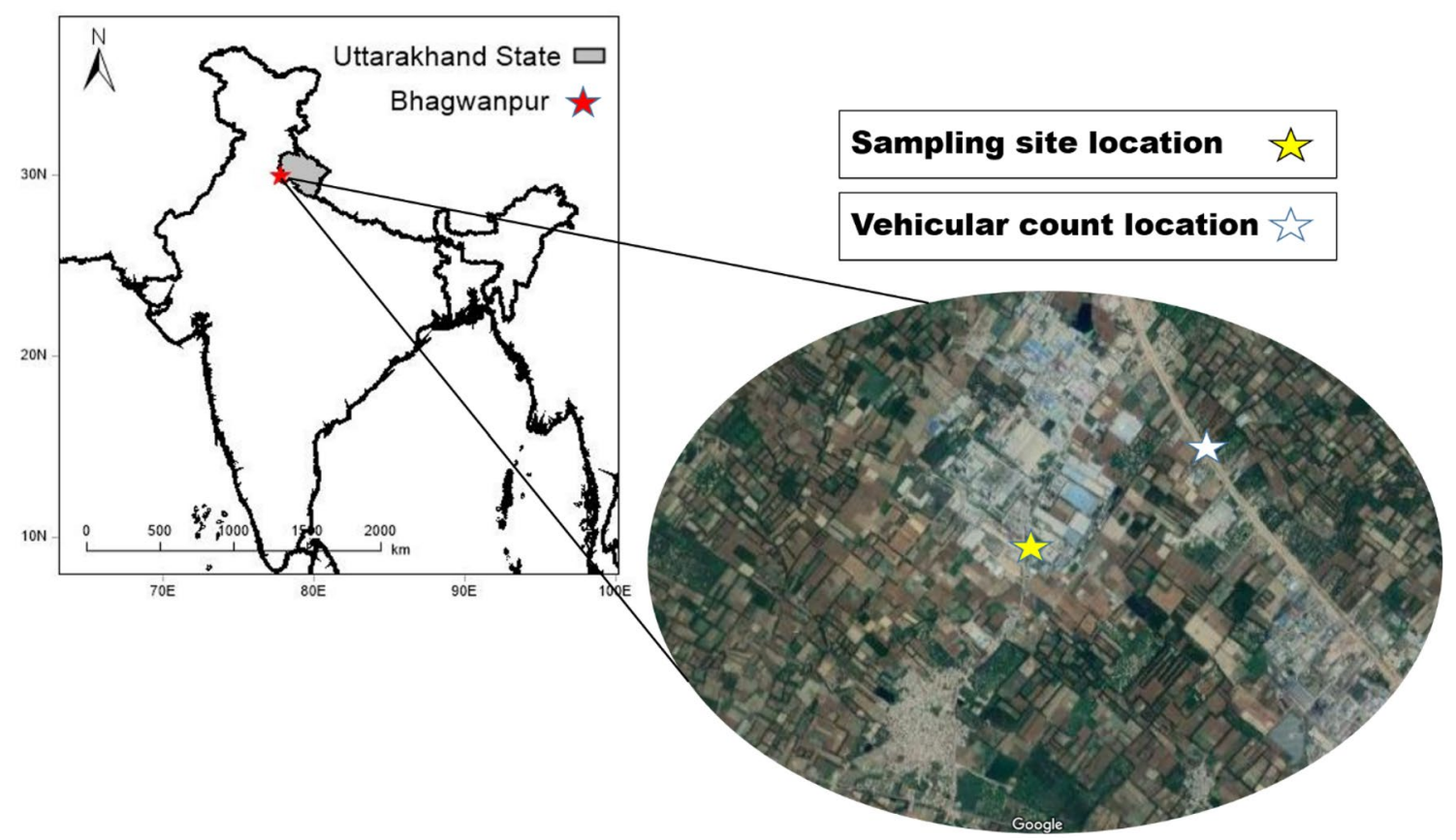

Fig. 1 Study site location in Bhagwanpur, Uttarakhand state, India. The location where vehicular count was performed is also mentioned

flow rate for the RDS was set at $1.1 \mathrm{~m}^{3} / \mathrm{min}$, and the sampling duration was $24 \mathrm{~h}$, from 6:00 AM of a day to 6:00 AM of the next day (IST). The RDS was placed on a building rooftop, $5 \mathrm{~m}$ above the ground level, while the $\mathrm{ACl}$ was placed 1.5 meters above the ground level to represent the breathing height of an average adult. The glass microfiber filter papers used for both the samplers were kept in a vacuum desiccator for $48 \mathrm{~h}$ before pre and post weighing. The filter papers were weighed in triplicate by using a microbalance (model: XS105DU, Mettler Toledo, USA) and were transported in an airtight box. The filter papers were handled using powder-free gloves and non-serrated forceps. For every ten samples, one field blank was taken to the sampling site and back to the laboratory. About 40 samples each from the RDS and $\mathrm{ACl}$ were collected during the observation period-from the winter season (October, November, and December) of 2014 to the summer season (March, April, and May) of 2015.

Due to non-availability of meteorological station at the monitoring location, we could not able to obtain the meteorological parameters such as wind speed, wind direction, temperature, and relative humidity. So, we collected the information of these parameters during the study period from the neighbouring $(\sim 10 \mathrm{~km})$ station located in the National Institute of Hydrology, Roorkee (lat: 29 $9^{\circ} 52^{\prime}$ 07.3" N, long: 7753'39.3" E, and altitude: 268 m ASL) (Fig. 2). Daily atmospheric boundary layer height was acquired from National Oceanic and Atmospheric Administration Real-Time Environmental Applications and Display System
(NOAA-READY) archived Global Data Assimilation System (GDAS) meteorological data $\left(0.5^{\circ} \times 0.5^{\circ}\right)$ once in every week during the study period (ftp://arlftp.arlhq.noaa.gov/pub/ archives/gdas0p5). The 3-h resolution (5:30 AM, 8:30 AM, 11:30 AM, 2:30 PM, 5:30 PM, 8:30 PM, 11:30 PM, and 2:30 AM) ARL format data was read using Hybrid Single Particle Lagrangian Integrated Trajectory (HYSPLIT) model-4.

\subsection{Elemental composition of RSPM}

About 1/10th $\left(51.61 \mathrm{~cm}^{2}\right)$ portion of the exposed filter paper was subjected to chemical analysis for estimating the concentration of trace elements. The mass concentrations of 13 trace elements $(\mathrm{Pb}, \mathrm{Cd}, \mathrm{Ni}, \mathrm{Co}, \mathrm{Mg}, \mathrm{Al}$, $\mathrm{Mn}, \mathrm{K}, \mathrm{Ca}, \mathrm{Cr}, \mathrm{Fe}, \mathrm{Cu}$, and $\mathrm{Zn}$ ) were determined through Inductively Coupled Plasma-Optical Emission Spectroscopy (ICP-OES) (Teledyne Leeman Labs, USA). The filter papers were digested using a mixture of $\mathrm{HNO}_{3}$ and $\mathrm{HClO}_{4}$ in the ratio 4:1 [20] in a microwave digester (MARS 6, CEM, USA), automated with a ramp time of $15 \mathrm{~min}$, hold time of $20 \mathrm{~min}$, temperature of $180^{\circ} \mathrm{C}$, and power of $1600 \mathrm{~W}$. Further, the digested solution was filtered through a syringe filter paper. Final extracts were refrigerated at $4^{\circ} \mathrm{C}$ in highdensity polyethylene bottles until further analysis with ICP-OES. The values obtained from the blank filter paper were subtracted from the sample values. A similar protocol was followed in an earlier study conducted by the same research group $[18,21]$. 
Fig. 2 Variation in meteorological parameters during the study period. Winter season represents October, November, and December months. Summer season represents March, April, and May months

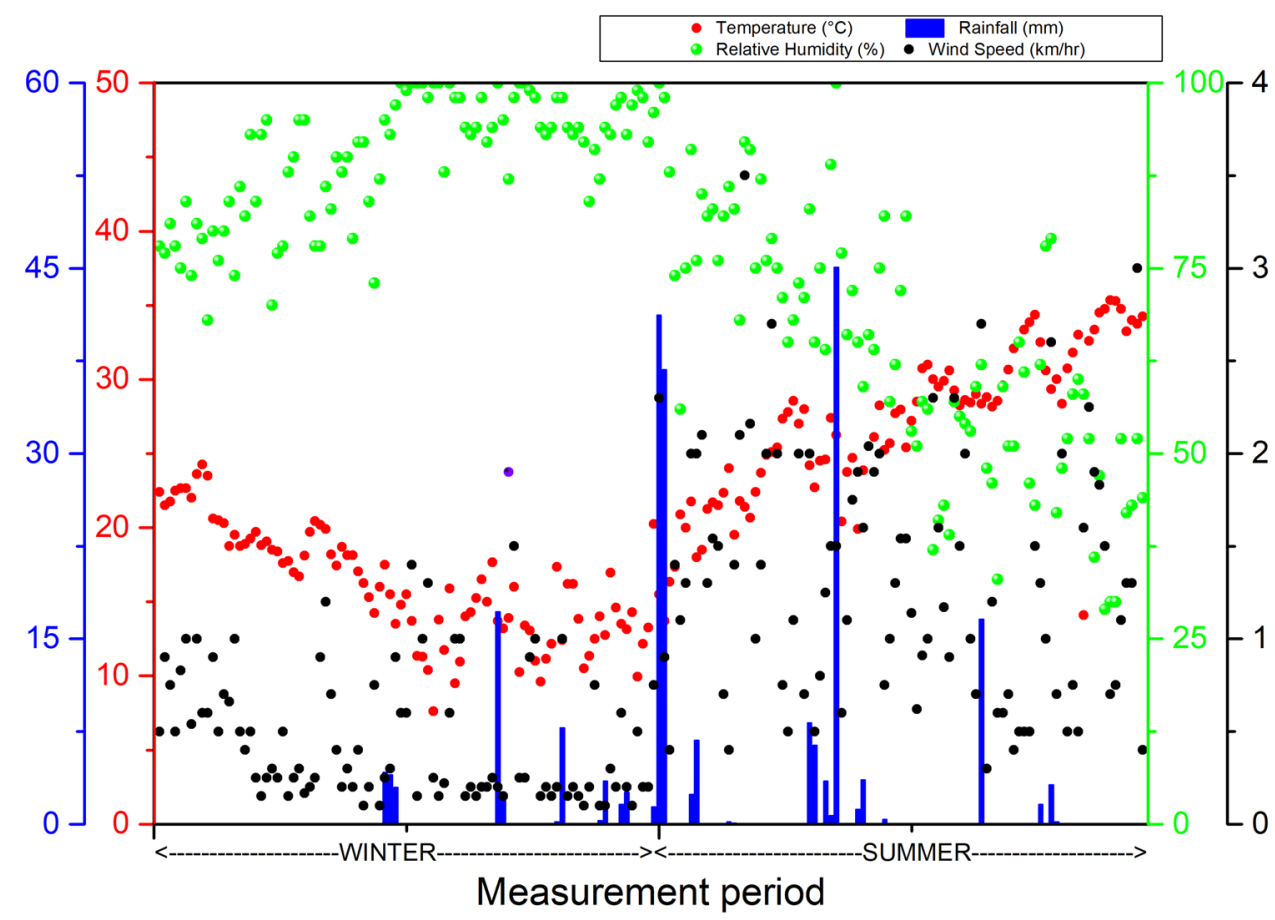

\subsection{Enrichment factor}

Several studies worldwide have shown the importance of using enrichment factor (EF) analysis as an effective tool in differentiating metallic pollution from natural or anthropogenic activity [22]. For calculating EF, the methodology proposed by Basha et al. [12] was adopted. The information on the concentration of trace elements in the earth's crust was obtained from an earlier study [23]. Further, aluminum was used as the reference material for calculating the EF [24]. In general, elements with concentrations in the earth's crust substantially higher than that of other elements are chosen as reference elements.

If $\mathrm{EF} \leq 1$, the element was considered to have been predominantly derived from the earth's crust. If $1<\mathrm{EF} \leq 10$, the element was considered to have been enriched by anthropogenic activity [25]. If $\mathrm{EF}>10$, the element was considered to have been highly enriched by anthropogenic activity.

\subsection{Excess cancer risk}

Excess cancer risk (ECR) indicates the incremental probability of an individual developing cancer during their lifetime as a consequence of exposure to toxic heavy metals. ECR is calculated using the following equation:

$\mathrm{ECR}($ Inhalation $)=\frac{(\mathrm{C} \times \mathrm{ET} \times \mathrm{EF} \times \mathrm{ED} \times \mathrm{IUR})}{(\mathrm{AT})}$ where $C$ represents the mass concentration of heavy metals $\left(\mu \mathrm{g} / \mathrm{m}^{3}\right) ; E T$, exposure time $(8 \mathrm{~h} /$ day); EF, exposure frequency (184 days/year); ED, exposure duration ( 24 years); and AT, average time for the carcinogen (AT $=24 \mathrm{~h} /$ day $\times 24$ years $\times 184$ days). The inhalation unit risk for heavy metals such as $\mathrm{Cd}, \mathrm{Cr}$, and $\mathrm{Ni}$ was obtained from the US-EPA database (http://www.epa.gov/iris/). Further, the inhalation unit risk (IUC) for $\mathrm{Pb}$ was obtained from the California Environmental Protection Agency (CalEPA) database. The IUC value for $\mathrm{Pb}$ is $12.0 \times 10^{-6}\left(\mu \mathrm{g} / \mathrm{m}^{3}\right)^{-1}$ [26]. Previously, other researchers have also employed this technique in their work $[6,27]$. The acceptable value is $10^{-6}$ for a protection, and $10^{-4}$ is likely to be tolerable risk. In the present study, ECR was calculated for $\mathrm{Pb}, \mathrm{Ni}, \mathrm{Cr}$, and $\mathrm{Cd}$.

\subsection{Air mass back trajectory analysis and fire data}

To determine the effect of regional and/or long-rangetransported PM on the local air quality of Bhagwanpur, three-day air mass back trajectories converging at $500 \mathrm{~m}$ above the ground level were constructed using the Hybrid Single Particle Lagrangian Integrated Trajectory (HYSPLIT) model [28]. The height of $500 \mathrm{~m}$ was chosen to represent the state of air parcel movement nearby the average boundary layer height $(561.3 \mathrm{~m})$ found during the study period over Bhagwanpur. The air mass back trajectories were generated for the period November 2014 to January 2015 to represent winter season and March 2015 to May 2015 to represent summer season. National Center for Environmental Prediction (NCEP) reanalysis 
meteorological data $\left(2.5^{\circ} \times 2.5^{\circ}\right)$ were utilized for generating the air mass back trajectories (ftp://arlftp.arlhq.noaa. gov/pub/archives/reanalysis/). Trajectories were calculated at 12:00 (HH:MM) Universal Time Coordinate (UTC) to provide comprehensive information on the air parcel over the monitoring location.

Fire data around the study site were obtained from the moderate resolution imaging spectroradiometer (MODIS) (https://firms.modaps.eosdis.nasa.gov/). The MODIS derived fire data uses $1 \mathrm{~km}$ channel with wavelengths of 4 and $11 \mu \mathrm{m}$. The shape file of the fire data was obtained, and only those fires with a detection confidence greater than $80 \%$ were considered [29]. MODIS fire detection uses a contextual algorithm that exploits the emission of midinfrared radiation from fires [30].

\section{Results and discussion}

\subsection{Size-segregated PM mass concentration}

The overall mean \pm standard deviation of RSPM was observed to be $259.6 \pm 52.6 \mu \mathrm{g} / \mathrm{m}^{3}$. The range and mean of RSPM during the winter season were observed to be $192.3-370.6 \mu \mathrm{g} / \mathrm{m}^{3}$ and $284.6 \mu \mathrm{g} / \mathrm{m}^{3}$, respectively. The respective values during the summer season were $167.2-313.7 \mu \mathrm{g} / \mathrm{m}^{3}$ and $234.5 \mu \mathrm{g} / \mathrm{m}^{3}$, respectively. The high PM mass concentration during the winter season can be attributed to meteorological conditions such as low boundary layer height $(297.3 \mathrm{~m})$ and low wind speed $(0.52 \mathrm{~km} / \mathrm{h})$. On all sampling days, the $24-\mathrm{h}$ RSPM mass concentration exceeded the permissible limit by Central Pollution Control Board (CPCB), $100 \mu \mathrm{g} / \mathrm{m}^{3}$ [31], and WHO, $50 \mu \mathrm{g} / \mathrm{m}^{3}$ [32]. Despite Bhagwanpur being a rural site, the 24-h RSPM mass concentration exceeded that of some highly polluted sites in India, such as Kakinada [11], Hisar [33], Kanpur [34], and Raipur [7], as well as that in a few major cities in Uttarakhand, namely Dehradun and Rishikesh [35].

The mass concentration range of $\mathrm{PM}_{0.4-10}$ during the winter and summer seasons was observed to be $162.9-217.4$ and $156.0-190.7 \mu \mathrm{g} / \mathrm{m}^{3}$, respectively (Fig. 3). The Student's $t$ test indicated that the mean concentrations of $\mathrm{PM}_{9.0-10}, \mathrm{PM}_{2.1-3.3}, \mathrm{PM}_{1.1-2.1}$, and $\mathrm{PM}_{0.7-1.1}$ differed significantly between the winter and summer seasons $(p<0.05)$. In contrast, the mean concentrations of $\mathrm{PM}_{5.8-9.0}$ $(p>0.05, t=0.81), \mathrm{PM}_{4.7-5.8}(p>0.05, t=-1.3), \mathrm{PM}_{3.3-4.7}$ $(p>0.05, t=1.21)$, and $\mathrm{PM}_{0.4-0.7}(p>0.05, t=-1.63)$ were non-significant. Among the measured PM in various size fractions, $\mathrm{PM}_{2.1-10 \mu \mathrm{m}}$ was considered the coarse fraction, while $\mathrm{PM}_{0.4-2.1 \mu \mathrm{m}}$ was considered the fine fraction. The 24-h average mass concentrations of fine $\mathrm{PM}\left(\mathrm{PM}_{0.4-2.1 \mu \mathrm{m}}\right)$ and coarse PM (PM 2.1-10 $\mu \mathrm{m})$ were observed to be statistically nonsignificant $(p>0.05, t=1.57)$ between weekdays and weekends. This phenomenon can be attributed to the continuous operation of industries around the study site.

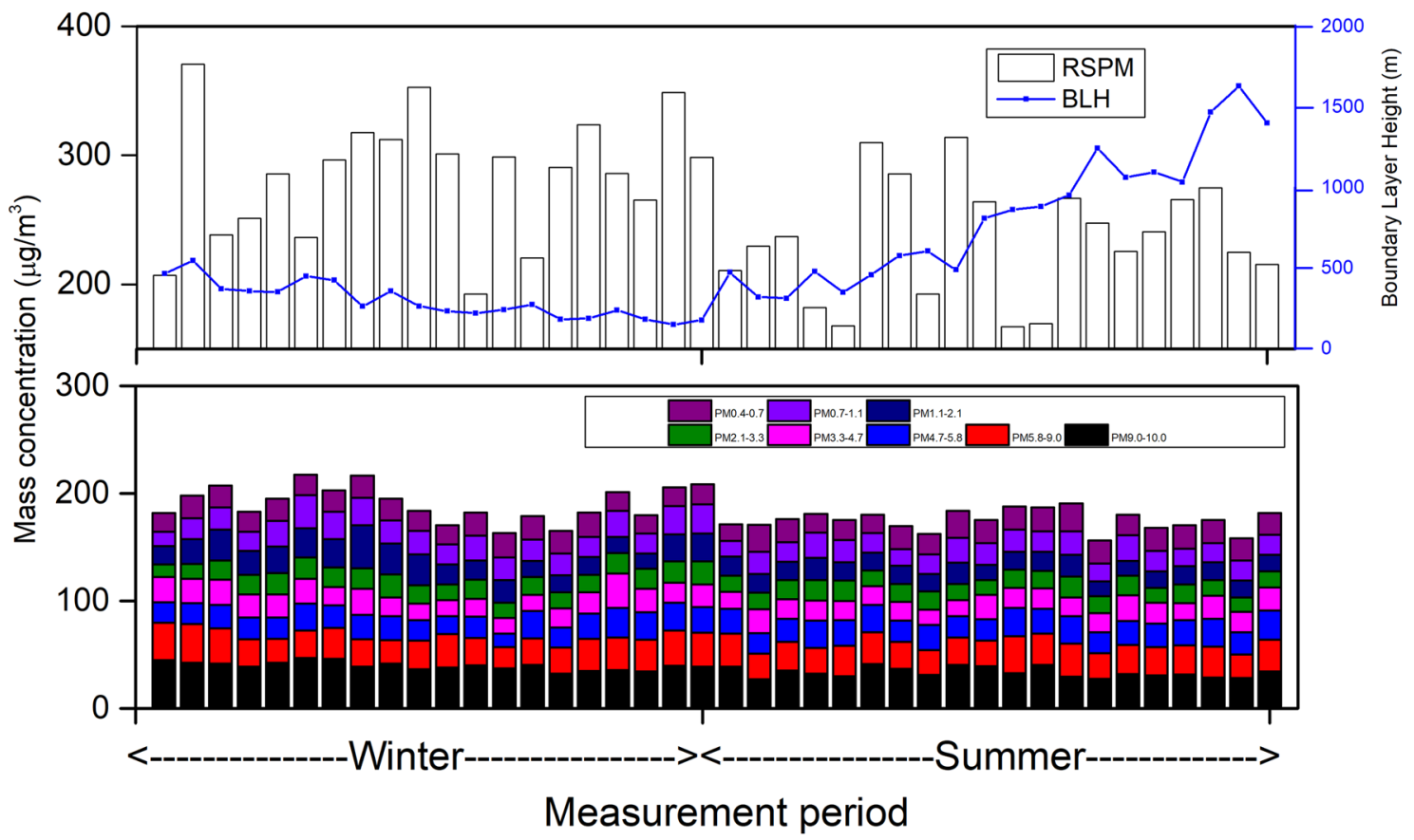

Fig. 3 Variation in RSPM measured through RDS along with boundary layer height (BLH) and size-segregated PM measured through ACI during the measurement period 
As a contrasting example, a significant difference between the $\mathrm{PM}_{10}$ concentrations on weekdays and weekends was observed in Chennai, India, where vehicular emission was reported as the main source of PM contribution [36].

During the winter and summer seasons, the ratio of fine and coarse fractions was 0.51 and 0.48 , respectively. This implies that the PM concentration measured at the study site had major contributions from coarse particles. The literature reveals that the coarse particles in the atmosphere are mostly derived from soil/crustal re-suspension [37]. The roads adjacent to the study site were not paved with tar or concrete, thereby increasing the possibility of high dust re-suspension [38]. In both winter and summer seasons, the PM concentration was found to be highest for $\mathrm{PM}_{9.0-10 \mu \mathrm{m}}$ and lowest for $\mathrm{PM}_{2.1-3.3 \mu \mathrm{m}}$. At Dehradun, the capital city of Uttarakhand located $\sim 59 \mathrm{~km}$ from Bhagwanpur, the ratio of fine $\left(\mathrm{PM}_{0.4-2.1 \mu \mathrm{m}}\right)$ and coarse $\left(\mathrm{PM}_{2.1-10 \mu \mathrm{m}}\right)$ PM was observed to be 0.47 and 0.44 at a commercial and residential site. Moreover, the PM concentration was observed to be highest in the size range of $\mathrm{PM}_{9.0-10 \mu \mathrm{m}}$ and lowest in $\mathrm{PM}_{0.4-1.1 \mu \mathrm{m}}$ [39].

On comparing the results obtained from RDS and $\mathrm{ACl}$, it was observed that RSPM concentration was 1.4 times higher than $\mathrm{PM}_{0.4-10}$ concentration. During winter and summer season, about 1.5 and 1.3 times, higher concentration was observed in RSPM compared to that of $\mathrm{PM}_{0.4-10}$, respectively.

\subsection{Relationship between PM and meteorological parameters}

The average temperature (temp), relative humidity $(\mathrm{RH})$, wind speed (WS), and boundary layer height (BLH) were observed to be $21.5^{\circ} \mathrm{C}, 74.7 \%, 1.0 \mathrm{~km} / \mathrm{h}$, and $561.3 \mathrm{~m}$, respectively, during the measurement period. Pearson's correlation was established between the size-segregated PM concentration and the meteorological parameters such as temp, WS, $\mathrm{RH}$, and $\mathrm{BLH}$. A negative correlation was observed for temp ( $r=-0.32$ for RSPM; $r=-0.22$ for $\mathrm{PM}_{2.1-10}$; and $r=-0.22$ for $\left.\mathrm{PM}_{0.4-2.1}\right)$, WS $(r=-0.34$ for RSPM; $r=-0.08$ for $\mathrm{PM}_{2.1-10}$; and $r=-0.36$ for $\mathrm{PM}_{0.4-2.1}$ ), and BLH ( $r=-0.31$ for RSPM and $r=-0.37$ for $\mathrm{PM}_{0.4-10}$ ). The average BLH during sampling days in winter season was $297.3 \mathrm{~m}$, but expanded to $825.4 \mathrm{~m}$ in summer season. The increasing local air temperature enhances the turbulence/dispersion resulting in deepening of BLH. Hence, temperature and BLH were negatively correlated with the PM concentration.

In contrast, a positive correlation was observed for $\mathrm{RH}\left(r=0.32\right.$ for RSPM; $r=0.20$ for $\mathrm{PM}_{2.1-10}$; and $r=0.22$ for $\left.\mathrm{PM}_{0.4-2.1}\right)$. High $\mathrm{RH}$ in the area can be attributed to the surrounding natural vegetation and river streams. High $\mathrm{RH}$ plays an important role in the secondary aerosol formation that can elevate PM mass concentration in the atmosphere $[40,41]$. Increasing $\mathrm{RH}$ can also reduce the removal rate of airborne PM through the scavenging effect [42]. Therefore, positive correlation between PM concentration and $\mathrm{RH}$ could be mainly due to secondary aerosol formation. A detailed quantification of secondary aerosol formation is beyond the scope of this study.

\subsection{Chemical species comprising RSPM}

In this study, 13 trace elements associated with RSPM were quantified. The estimated trace elements constituted around $13.17 \%$ of the RSPM. The concentrations of crustal elements ( $\mathrm{Ca}, \mathrm{Mg}, \mathrm{K}$, and $\mathrm{Al}$; average concentration: $6.87 \mu \mathrm{g} / \mathrm{m}^{3}$ ) were found to be higher than those of anthropogenic elements $(\mathrm{Cd}, \mathrm{Co}, \mathrm{Ni}, \mathrm{Pb}, \mathrm{Cr}, \mathrm{Zn}$, and $\mathrm{Cu}$; average concentration: $0.62 \mu \mathrm{g} / \mathrm{m}^{3}$ ) (Table 1). The mean mass concentrations of the elements were in the order $\mathrm{Ca}>\mathrm{K}>\mathrm{Mg}$ $>\mathrm{Al}>\mathrm{Zn}>\mathrm{Fe}>\mathrm{Mn}>\mathrm{Cr}>\mathrm{Co}>\mathrm{Ni}>\mathrm{Cu}>\mathrm{Pb}>\mathrm{Cd}$. Among the trace elements analyzed, $\mathrm{Ca}$ had the highest concentration $3.9-19.5 \mu \mathrm{g} / \mathrm{m}^{3}$ during the winter season and $5.0-17.4 \mu \mathrm{g} /$ $\mathrm{m}^{3}$ during the summer season, while $\mathrm{Cd}$ had the lowest concentration $0.02 \times 10^{-1}-0.01 \mu \mathrm{g} / \mathrm{m}^{3}$ during the winter season and $0.01 \times 10^{-1}-0.01 \mu \mathrm{g} / \mathrm{m}^{3}$ during the summer season. The average Ca concentration in this study was found to be significantly higher than other industrial centers reported in previous studies: 1.4 times higher than that in New Delhi [43] and 1.9 times higher than that in Argentina [44]. Similarly, Sharma et al. [45] reported higher Ca levels near a cement plant in Chhattisgarh, India. The average concentrations of metals such as $\mathrm{Ni}, \mathrm{Pb}, \mathrm{Mn}, \mathrm{Cu}$, and $\mathrm{Zn}$ found in this study were higher than those observed in a coastal industrial city in a previous study [2]. Further, the $\mathrm{Cd}$ concentration observed in this study was higher than that reported in Spain and Norway but less than that in New Delhi [46]. In addition, the average concentrations of all elements were higher in the winter season than in the summer season. Further, the 24-h average concentration of $\mathrm{Pb}\left(0.07 \mu \mathrm{g} / \mathrm{m}^{3}\right)$ was less than the permissible limit by CPCB $\left(1.0 \mu \mathrm{g} / \mathrm{m}^{3}\right)$.

Pearson's correlation between the elements revealed that several elements were highly correlated with each other (Fig. 4). Co had high correlation with $\mathrm{Cr}(0.80), \mathrm{Cu}$ (0.88), and $\mathrm{Ni}(0.70)$. Similarly, Cu had high correlation with $\mathrm{Cr}(0.88)$. These observations indicate that these anthropogenic elements had similar sources. Further, the Kurtosis test conducted on the elements revealed mixed results: Some elements such as $\mathrm{Cd}, \mathrm{Pb}, \mathrm{Mg}, \mathrm{Al}, \mathrm{Ca}$, and $\mathrm{Zn}$ showed negative values, whereas elements such as $\mathrm{Co}, \mathrm{Ni}, \mathrm{K}, \mathrm{Cr}$, $\mathrm{Mn}, \mathrm{Fe}$, and $\mathrm{Cu}$ showed positive values. Negative values denote a flat distribution of the data, while positive values 


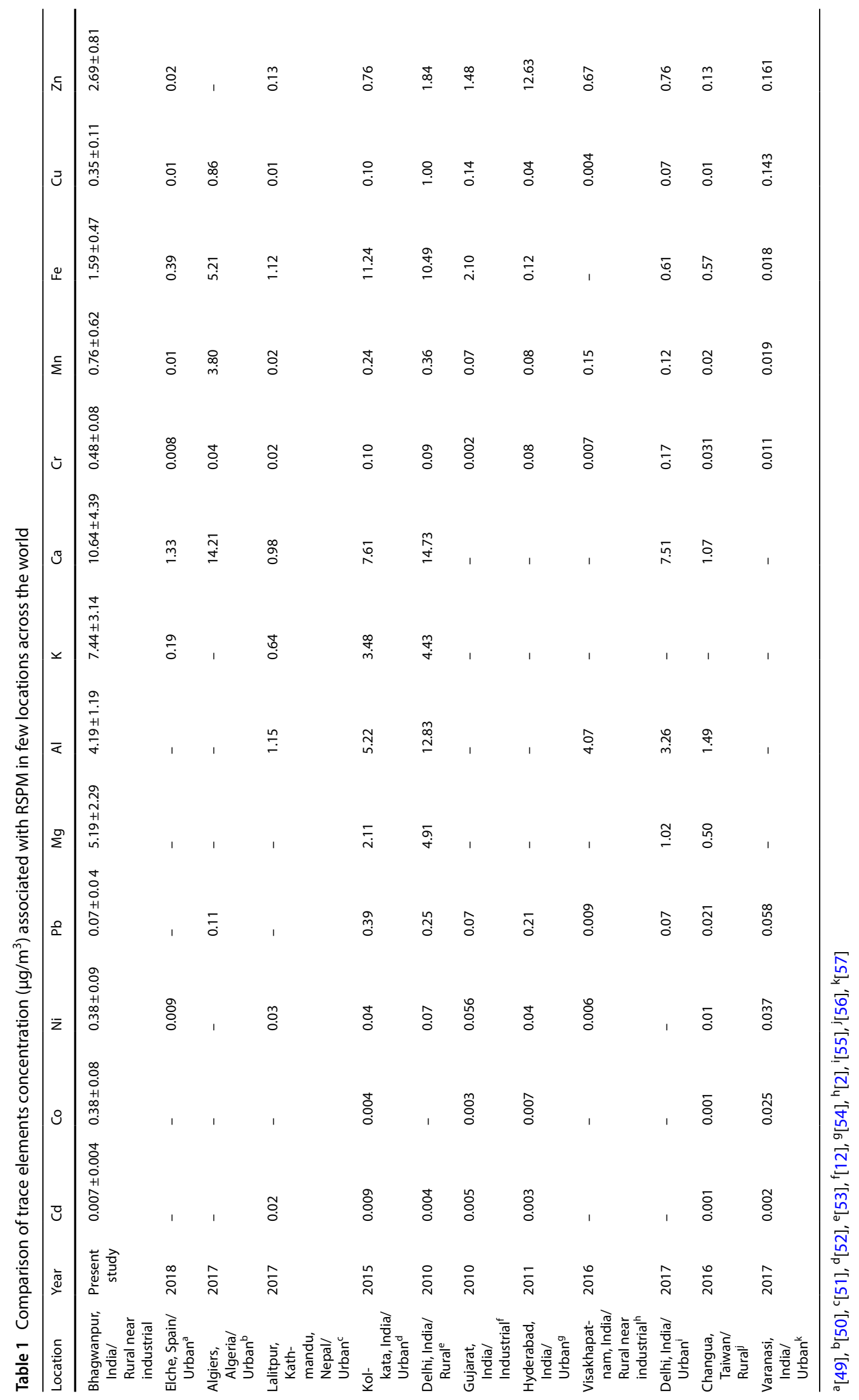




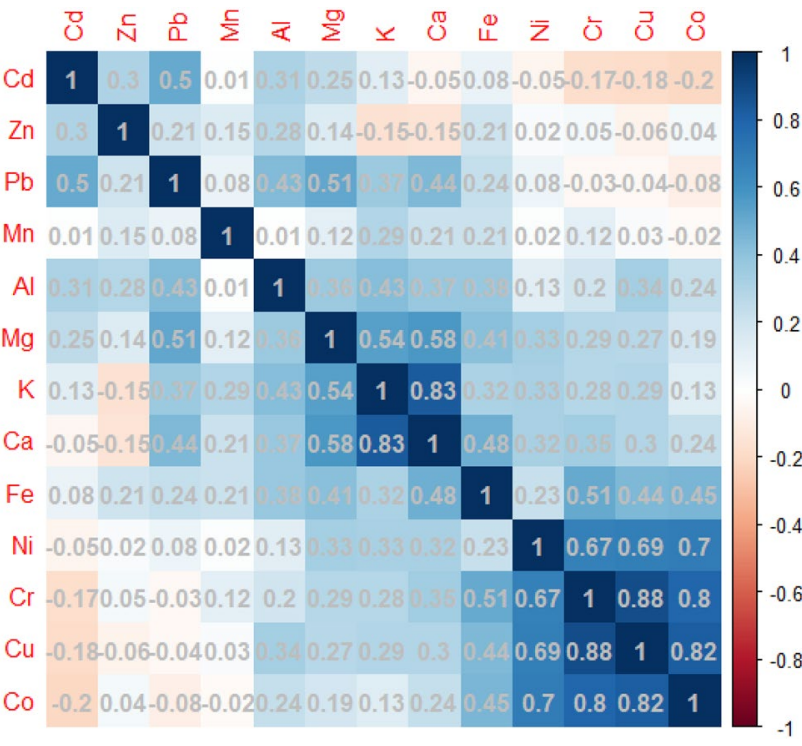

Fig. 4 Pearson's correlation plot among the estimated trace elements

denote sporadic high emissions $[47,48]$. Figure S4 shows a box and whisker plot of the estimated trace elements.

\subsection{Enrichment factor (EF) and principal component analysis (PCA)}

The enrichment factor (EF) of elements such as $\mathrm{Fe}(0.6)$ and $\mathrm{Al}$ (1.0) was $\leq 1$. Further, the EF of $\mathrm{Ca}$ (5.1), $\mathrm{K}(7.1)$, and $\mathrm{Mg}$ (4.4) was found to be $<10$, denoting considerable anthropogenic activity. Elements such as $\mathrm{Zn}(766.4), \mathrm{Co}(312.6)$, $\mathrm{Cu}$ (117.5), Pb (103.0), Cr (94.0), Ni (91.0), and Mg (16.0) showed high EF was chiefly attributable to various industrial processes, while $\mathrm{Cd}(10,094.1)$ showed highest EF [49, 58]. Similarly, a study conducted in Chennai revealed high $\mathrm{EF}$ for elements such as $\mathrm{Cd}, \mathrm{Ni}, \mathrm{As}, \mathrm{Zn}, \mathrm{Pb}, \mathrm{Ba}, \mathrm{Cu}$, and V; the high level of EF was attributed to the industrial processes in the vicinity of the monitoring site [14].

In environmental studies, factor analysis is often used to simplify complex data sets for identifying the sources of pollution [50]. In this study, principal component analysis (PCA) was conducted using varimax-rotated factor analysis, and the minimum number of samples required for performing PCA was maintained. The factors having an eigenvalue of more than one were considered (Table 2). PCA revealed three principal components representing a cumulative variance of about $65.6 \%$. The first component, responsible for about $28.2 \%$ of the variance, comprised $\mathrm{Co}, \mathrm{Ni}, \mathrm{Cu}$, and $\mathrm{Cr}$. These elements could have possibly originated from various industrial activities: Ni from electroplating industries; Cu from smelting activities and metallurgical industries; $\mathrm{Cr}$ from chromium
Table 2 Varimax-rotated factor loading matrix for the estimated trace elements during the study period

\begin{tabular}{|c|c|c|c|}
\hline & \multicolumn{3}{|c|}{ Component } \\
\hline & 1 & 2 & 3 \\
\hline $\mathrm{Cd}$ & & & 0.77 \\
\hline Co & 0.93 & & \\
\hline $\mathrm{Ni}$ & 0.77 & & \\
\hline $\mathrm{Pb}$ & & & 0.66 \\
\hline $\mathrm{Mg}$ & & 0.62 & \\
\hline Al & & & 0.61 \\
\hline K & & 0.88 & \\
\hline $\mathrm{Ca}$ & & 0.89 & \\
\hline $\mathrm{Cr}$ & 0.91 & & \\
\hline \multicolumn{4}{|l|}{$\mathrm{Mn}$} \\
\hline \multicolumn{4}{|l|}{$\mathrm{Fe}$} \\
\hline $\mathrm{Cu}$ & 0.92 & & \\
\hline$Z n$ & & & 0.68 \\
\hline Variance & 28.2 & 20.7 & 16.7 \\
\hline Cumulative variance & 28.2 & 48.9 & 65.6 \\
\hline
\end{tabular}

plating operations [51]; Co and $\mathrm{Cr}$ from incinerator emission and coal combustion [25,52]; and Ni, Co, and $\mathrm{Cr}$ from cement dust [59].

The second component, responsible for about 20.7\% of the variance, comprised $\mathrm{Mg}, \mathrm{K}$, and $\mathrm{Ca}$, which belong to crustal elements [54], and may have been generated by soil re-suspension. As the study site was surrounded by agricultural land, some Ca could also have been generated by the re-suspension of agricultural soil because of wind activity [13]. Moreover, along the sampling site, there is frequent movement of heavy vehicles carrying fine-particle materials such as cement bags and packaging materials, and these could be one of the sources of the second component.

The third component, responsible for about $16.7 \%$ of the variance, comprised $\mathrm{Cd}, \mathrm{Al}, \mathrm{Zn}$, and $\mathrm{Pb}$, which could have originated from vehicular activity. $\mathrm{Cd}$ is emitted because of brake and tire wear. $\mathrm{Pb}$ can be a part of vehicular emission. Though leaded fuel was banned in India in the year 2000 [55], traces of $\mathrm{Pb}$ are still found in road dust, as observed by Hsu et al. [56] and Pandey et al. [57]. $\mathrm{Zn}$ and $\mathrm{Al}$ may have originated from tire and brake pad wear of vehicles [60].

\subsection{Excess cancer risk (ECR)}

Among the elements analyzed in this study, $\mathrm{Cd}, \mathrm{Cr}, \mathrm{Ni}$, and $\mathrm{Pb}$ are known carcinogenic metals that can pose significant risks to human health. The carcinogenic group of these elements, as per the US Environmental Protection 
Agency's Integrated Risk Information System (IRIS), is given in Table 3. These carcinogenic elements can enter the human bloodstream through the inhalation pathway [27]. The mass concentration of carcinogenic $\mathrm{Cr}$ used for computing ECRs was calculated using a method proposed in an earlier study [47].

The ECR of the carcinogenic trace elements was in the order $\mathrm{Cr}>\mathrm{Ni}>\mathrm{Cd}>\mathrm{Pb}$. Although the concentration of $\mathrm{Cr}(\mathrm{VI})$ was less than that of $\mathrm{Pb}$ and $\mathrm{Cd}$, the $\mathrm{ECR}$ of $\mathrm{Cr}(\mathrm{VI})$ was highest because of higher IUR. The calculated ECR values are as follows: $\mathrm{Cr}: 2.72 \times 10^{-4}$; Ni: $0.3 \times 10^{-4} ; \mathrm{Cd}: 0.04 \times 10^{-4}$; and $\mathrm{Pb}: 0.28 \times 10^{-6}$. ECR for $\mathrm{Cr}$ was 2.7 times higher than the tolerance limit $\left(10^{-4}\right)$, while elements such as $\mathrm{Ni}$ and $\mathrm{Cd}$ were 30 and 4 times higher than the safe limit $\left(10^{-6}\right)$, respectively. ECR for $\mathrm{Pb}$ was below the safe limit, chiefly because of its low IUR $\left(12.0 \times 10^{-6}\right)$. The total ECR was calculated to be $3.06 \times 10^{-4}$, which indicates that ECR was around 3 times higher than the tolerance limit. Earlier, the $E C R$ values of these carcinogenic elements were reported to be lower than the tolerance risk and higher than the safe limit at Dehradun city [18].

\subsection{Back trajectory analysis and fire data}

The three-day air mass back trajectory analysis revealed that air masses mostly arrive through the North Western Indo-Gangetic Plains (NW-IGP), where huge quantities of crop residues are burned (Fig. 5). An earlier study reported that vast quantities of paddy (kharif crop) residues are burned in the NW-IGP region, resulting in emissions [61]. The number of fires $(\mathrm{Cl} \geq 80)$ observed during the winter and summer seasons was 2573 and 9373 , respectively. Every year, during the summer season, a prolonged dry and hot period leads to frequent forest fires in Uttarakhand [62]. A substantial number of trajectories pass through the mountainous region of Uttarakhand and Himachal Pradesh, where air masses get loaded with emissions from the forest fires. Soni et al. [19] reported that emissions from the forest fire in the neighboring mountains influence the local particulate pollution at Dehradun city. Also, during the summer season, some of these trajectories pass through the semiarid regions of Western India.

This analysis reveals that, in addition to the PM originating from vehicular emissions, industrial emissions, and road-side soil re-suspension, emissions from biomass

Table 3 Excess cancer risk of carcinogenic elements associated with respirable suspended particulate matter (IUR: inhalation unit risk)

\begin{tabular}{lllll}
\hline Element & Carcinogenic group & $\begin{array}{l}\text { Conc. } \\
\left(\mu \mathrm{g} / \mathrm{m}^{3}\right)\end{array}$ & $\begin{array}{l}\text { IUR } \\
\left(\mu \mathrm{g} / \mathrm{m}^{3}\right)^{-1}\end{array}$ & $\begin{array}{l}\text { ECR } \\
\left(\times 10^{-4}\right)\end{array}$ \\
\hline $\mathrm{Pb}$ & $\mathrm{B} 2$ (probable human carcinogen) & 0.072 & 0.000012 & 0.0028 \\
$\mathrm{Ni}$ & $\mathrm{A}$ (human carcinogen) & 0.382 & 0.00024 & 0.3000 \\
$\mathrm{Cd}$ & $\mathrm{B}$ ( probable human carcinogen) & 0.007 & 0.0018 & 0.0420 \\
$\mathrm{Cr}(\mathrm{VI})$ & $\mathrm{A}$ (human carcinogen) & 0.068 & 0.012 & 2.7200 \\
Total ECR & & & & 3.0648 \\
\hline
\end{tabular}
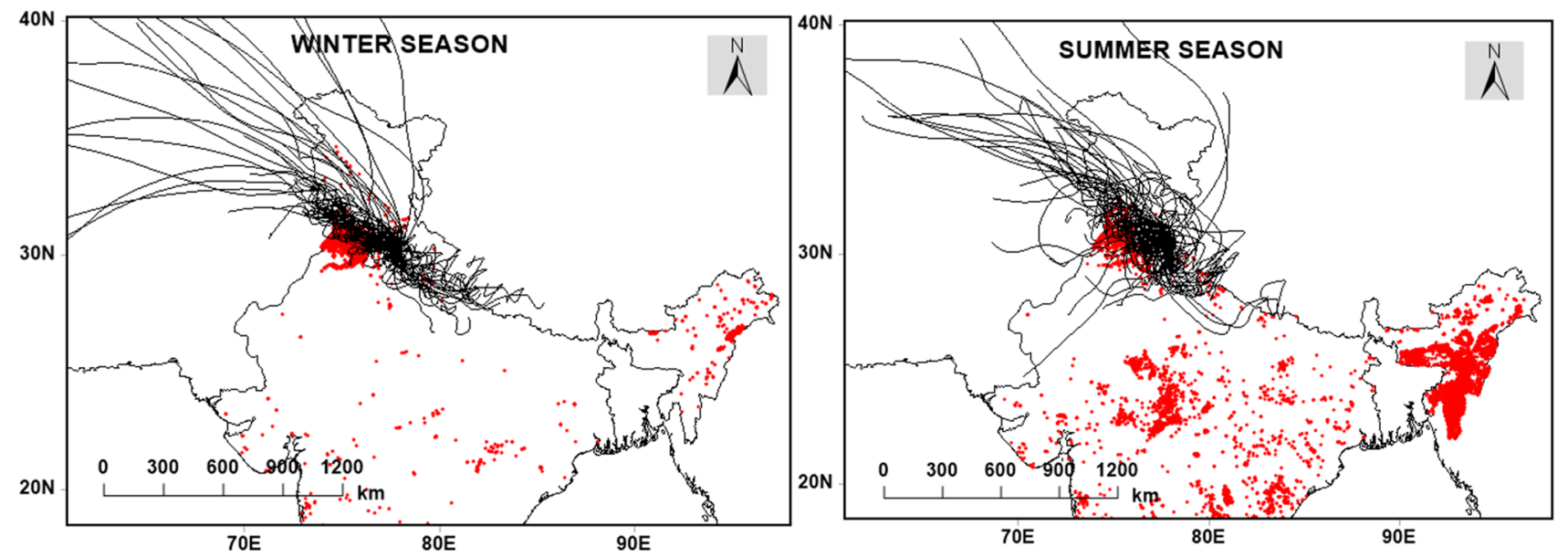

Fig. 5 Three-day air mass back trajectories converging over Bhagwanpur during winter and summer season are shown along with the respective MODIS fire spot 
burning also contribute to the deterioration of air quality in Bhagwanpur.

\section{Conclusions}

The present study is aimed at determining the mass concentrations of RSPM and $\mathrm{PM}_{0.4-10.0 \mu \mathrm{m}}$, divided into eight size fractions, at Bhagwanpur, an emerging industrial area located along the foothills of the Himalayas. The following results were found:

1. During all sampling days, the 24-h RSPM mass concentration was higher than the Indian national ambient air quality standard $\left(100 \mu \mathrm{g} / \mathrm{m}^{3}\right)$. Further, the mass concentration of coarse PM $\left(\mathrm{PM}_{2.1-10 \mu \mathrm{m}}\right)$ was greater than that of fine PM $\left(\mathrm{PM}_{0.4-2.1 \mu \mathrm{m}}\right)$. This observation was attributed to the unpaved roads neighbouring the study area.

2. Negative correlation was observed for PM with temp, WS, and BLH, while positive correlation was observed with $\mathrm{PM}$ and $\mathrm{RH}$.

3. Among the analyzed trace elements, $\mathrm{Ca}$ had the highest average concentration and $\mathrm{Cd}$ the lowest. Further, the $\mathrm{EF}$ analysis revealed high enrichment of $\mathrm{Cd}$ and $\mathrm{Pb}$, indicating substantial anthropogenic activity in the study area. PCA showed three components accounting for $65.6 \%$ of cumulative variance with contributions from industrial (28.2\%), vehicular (20.7\%), and crustal sources (16.7\%).

4. Excess cancer risk for $\mathrm{Cr}$ was 2.7 times higher than the tolerance level $\left(10^{-4}\right)$, while only $\mathrm{Pb}$ was below the safe limit $\left(10^{-6}\right)$. The total ECR for $\mathrm{Cr}, \mathrm{Cd}, \mathrm{Pb}$, and $\mathrm{Ni}$ was around 3 times higher than the tolerance level.

5. The 3-day air mass back trajectory analysis revealed significant influence of crop residue burning in NW-IGP and forest fire emissions in Uttarakhand and Himachal Pradesh.

Therefore, effective management strategies should be implemented to reduce the PM mass concentration at the study site. We believe this work on source apportionment and health impacts of atmospheric PM can play a key role in designing air pollution modeling and epidemiological studies.

Acknowledgements We are grateful to Prof. Kusum Arunachalam, Head of Department, School of Environment and Natural Resources, Doon University, for providing necessary support and infrastructure for our work.

Author's contribution We declare that all the authors have made individual contributions to the preparation of this manuscript. PP and
VS conceived and designed the study, and VP, AS, and DP analyzed the data.

\section{Compliance with ethical standards}

Conflict of interest The authors declare no conflict of interest.

\section{References}

1. Rana A, Jia S, Sarkar S (2019) Black carbon aerosol in India: a comprehensive review of current status and future prospects. Atmos Res 218:207-230. https://doi.org/10.1016/j.atmos res.2018.12.002

2. Police S, Sahu SK, Pandit GG (2016) Chemical characterization of atmospheric particulate matter and their source apportionment at an emerging industrial coastal city, Visakhapatnam, India. Atmos Pollut Res 7:725-733. https://doi.org/10.1016/j. apr.2016.03.007

3. Gour AA, Singh SK, Tyagi SK, Mandal A (2015) Variation in parameters of ambient air quality in National Capital Territory (NCT) of Delhi (India). Atmos Clim Sci 50:13-22

4. Banerjee T, Murari V, Kumar M, Raju MP (2015) Source apportionment of airborne particulates through receptor modelling: Indian scenario. Atmos Res 164-165:167-187. https://doi. org/10.1016/j.atmosres.2015.04.017

5. Tiwari S, Bisht DS, Srivastava AK (2015) CO and $\mathrm{NO}_{\mathrm{x}}$ variability at a locally polluted urban location in India. Nat Hazards 75:813829. https://doi.org/10.1007/s11069-014-1351-9

6. Izhar S, Goel A, Chakraborty A, Gupta T (2016) Annual trends in occurrence of submicron particles in ambient air and health risk posed by particle bound metals. Chemosphere 146:582-590. https://doi.org/10.1016/j.chemosphere.2015.12.039

7. Deshmukh D, Deb MK, Mkoma SL (2013) Size distribution and seasonal variation of size-segregated particulate matter in the ambient air of Raipur city, India. Air Qual Atmos Health 6:259276. https://doi.org/10.1007/s11869-011-0169-9

8. Ny MT, Lee B (2011) Size distribution of airborne particulate matter and associated metallic elements in an urban area of an industrial city in Korea. Aerosol Air Qual Res 11:643-653. https ://doi.org/10.4209/aaqr.2010.10.0090

9. Yadav M, Soni K, Soni BK, Singh NK, Bamniya BR (2019) Source apportionment of particulate matter, gaseous pollutants, and volatile organic compounds in a future smart city of India. Urban Clim 28:100470. https://doi.org/10.1016/j.uclim.2019.100470

10. Vijayanand C, Rajaguru P, Kalaiselvi K, Selvam KP, Palanivel M (2008) Assessment of heavy metal contents in the ambient air of the Coimbatore city, Tamilnadu, India. J Hazard Mater 160:548553. https://doi.org/10.1016/j.jhazmat.2008.03.071

11. Mohammed MP, Namuduri S (2013) Trace elemental composition in the atmospheric aerosols of Kakinada city, India. Sustain Environ Res 23:315-324

12. Basha S, Jhala J, Thorat R, Goel S, Trivedi R, Shah K, Menon G, Gaur P, Mody KH, Jha B (2010) Assessment of heavy metal content in suspended particulate matter of coastal industrial town, Mithapur, Gujarat, India. Atmos Res 97:257-265. https://doi. org/10.1016/j.atmosres.2010.04.012

13. Sharma SK, Sharma A, Saxena M, Choudhary N, Masiwal R, Mandal TK, Sharma C (2016) Chemical characterization and source apportionment of aerosol at an urban area of Central Delhi, India. Atmos Pollut Res 7:110-121. https://doi. org/10.1016/j.apr.2015.08.002 
14. Panda S, Nagendra SMS (2018) Chemical and morphological characterization of respirable suspended particulate matter (PM 10) and associated heath risk at a critically polluted industrial cluster. Atmos Pollut Res. https://doi.org/10.1016/j. apr.2018.01.011

15. Liu S, Ganduglia CM, Li X, Delclos GL, Franzini L, Zhang K (2016) Fine particulate matter components and emergency department visits among a privately insured population in Greater Houston. Sci Total Environ 566-567:521-527. https:// doi.org/10.1016/j.scitotenv.2016.05.022

16. Kompalli SK, Babu SS, Bharatan LN, Moorthy KK (2016) Springtime enhancement in aerosol burden over a high-altitude location in western trans-Himalaya: results from long-term observations. Curr Sci 111:117-131. https://doi.org/10.18520 /cs/v111/i1/117-131

17. Raatikainen $T$, Brus $D$, Hooda RK, Hyvarinen AP, Asmi E, Sharma VP, Arola A, Lihavainen H (2017) Size-selected black carbon mass distributions and mixing state in polluted and clean environments of northern India. Atmos Chem Phys 17:371383. https://doi.org/10.5194/acp-17-371-2017

18. Soni A, Kumar U, Prabhu V, Shridhar V (2020) Characterization, source apportionment and carcinogenic risk assessment of atmospheric particulate matter at Dehradun, situated in the Foothills of Himalayas. J Atmos Solar-Terr Phys 199:105205. https://doi.org/10.1016/j.jastp.2020.105205

19. Soni A, Decesari S, Shridhar V, Prabhu V, Panwar P, Marinoni A (2019) Investigation of potential source regions of atmospheric Black Carbon in the data deficit region of the Western Himalayas and its foothills. Atmos Pollut Res. https://doi. org/10.1016/j.apr.2019.07.015

20. Gelandi P, Adams S (1978) Chemical characteristics and source apportionment of fine particulate organic carbon in Hong Kong during high particulate matter episodes in winter 2003. Anal Chim Acta 96:229-241. https://doi.org/10.1016/j.atmos res.2012.08.005

21. Prabhu V, Shridhar V (2019) Investigation of potential sources, transport pathway, and health risks associated with respirable suspended particulate matter in Dehradun city, situated in the foothills of the Himalayas. Atmos Pollut Res 10:87-196. https ://doi.org/10.1016/j.apr.2018.07.009

22. Hu ZM, Wang J, Chen YY, Chen ZL, Xu SY (2014) Concentrations and source apportionment of particulate matter in different functional areas of Shanghai, China. Atmos Pollut Res 5:138-144. https://doi.org/10.5094/apr.2014.017

23. Taylor SR (1964) Abundance of chemical elements in the continental crust: a new table. Geochim Cosmochim Acta 28:1273-1285. https://doi.org/10.1016/0016-7037(64)90129 $-2$

24. Pipalatkar P, Khaparde VV, Gajghate DG, Bawase MG (2014) Source apportionment of PM2.5 using a CMB model for a centrally located Indian city. Aerosol Air Qual Res 14:1089-1099. https://doi.org/10.4209/aaqr.2013.04.0130

25. Gao Y, Nelson ED, Field MP, Ding Q, Li H, Sherrell RM, Gigliotti CL, Van DL, Glenn TR, Eisenreich SJ (2002) Characterization of atmospheric trace elements on PM2.5 particulate matter over the New York-New Jersey harbor estuary. Atmos Environ 36:1077-1086. https://doi.org/10.1016/S1352-2310(01)00381-8

26. Khanna I, Khare M, Gargava P (2015) Health risks associated with heavy metals in fine particulate matter: a case study in Delhi city, India. J Geosci Environ Prot 3:72-77. https://doi.org/10.4236/ gep.2015.32012

27. Hieu NT, Lee BK (2010) Characteristics of particulate matter and metals in the ambient air from a residential area in the largest industrial city in Korea. Atmos Res 98:526-537. https://doi. org/10.1016/j.atmosres.2010.08.019
28. Draxler R, Rolph G (2003) Hybrid single-particle lagrangian integrated trajectory (HYSPLIT) model. NOAA Air Resour. Lab, Silver Spring

29. Sen A, Abdelmaksoud AS, Ahammed NY, Alghamdi M, Banerjee T, Bhat MA, Chatterjee A, Choudhuri AK, Das T, Dhir A, Dhyani PP, Gadi R, Ghosh S, Kumar K, Khan AH, Khoder M, Kumari KM, Kuniyal JC, Kumar M, Lakhani A, Mahapatra PS, Naja M, Pal D, Pal D, Rafiq M, Romshoo SA, Rashid I, Saikia P, Shenoy DM, Sridhar V, Verma N, Vyas BM, Saxena M, Sharma A, Sharma SK, Mandal TK (2017) Variations in particulate matter over Indo-Gangetic Plains and Indo-Himalayan Range during four field campaigns in winter monsoon and summer monsoon: role of pollution pathways. Atmos Environ 154:200-224. https://doi.org/10.1016/j. atmosenv.2016.12.054

30. Giglio L, Descloitres J, Justice CO, Kaufman YJ (2003) An enhanced contextual fire detection algorithm for MODIS. Remote Sens Environ 87:273-282. https://doi.org/10.1016/ S0034-4257(03)00184-6

31. CPCB (2019) National Ambient Air Quality Standard. https:// cpcb.nic.in/National-Air-Quality-Index/

32. WHO (2005) WHO air quality guidelines for particulate matter, ozone, nitrogen dioxide and sulfur dioxide. http://whqlibdoc. who.int/hq/2006/WHO_SDE_PHE_OEH_06.02_eng.pdf

33. Haritash AK, Kaushik CP (2007) Assessment of seasonal enrichment of heavy metals in respirable suspended particulate matter of a sub-urban Indian City. Environ Monit Assess 128:411420. https://doi.org/10.1007/s10661-006-9335-1

34. Sharma M, Maloo S (2005) Assessment of ambient air PM10 and PM2.5 and characterization of PM10 in the city of Kanpur, India. Atmos Environ 39:6015-6026. https://doi.org/10.1016/j.atmos env.2005.04.041

35. UEPPCB (2015) Ambient air quality. http://ueppcb.uk.gov.in/ pages/display/95-air-quality-data

36. Srimuruganandam B, Nagendra SMS (2011) Chemical characterization of PM10 and PM2.5 mass concentrations emitted by heterogeneous traffic. Sci Total Environ 409:3144-3157. https:// doi.org/10.1016/j.scitotenv.2011.04.042

37. Seinfeld JH, Pandis SN (1998) Atmospheric chemistry and physics: from air pollution to climate change. Wiley, New York. ISBN 0471178160

38. Pinnick RG, Fernandez G, Hinds BD, Bruce CW, Schaefer RW, Pendleton JD (1985) Dust generated by vehicular traffic on unpaved roadways: sizes and infrared extinction characteristics. Aerosol Sci Technol 4:99-121. https://doi.org/10.1080/0278682850 8959042

39. Prabhu V, Gupta SK, Madhwal S, Shridhar V (2019) Exposure to atmospheric particulates and associated respirable deposition dose to street vendors at residential and commercial site in Dehradun city. Health Work, Saf. https://doi.org/10.1016/j. shaw.2019.01.005

40. Qu WJ, Wang J, Zhang XY, Wang D, Sheng LF (2015) Influence of relative humidity on aerosol composition: impacts on light extinction and visibility impairment at two sites in coastal area of China. Atmos Res 153:500-511. https://doi.org/10.1016/j. atmosres.2014.10.009

41. Zang L, Wang Z, Zhu B, Zhang Y (2019) Roles of relative humidity in aerosol pollution aggravation over central China during wintertime. Int J Environ Res Public Health. https://doi.org/10.3390/ ijerph 16224422

42. Kulshrestha A, Satsangi PG, Masih J, Taneja A (2009) Metal concentration of PM2.5 and PM10 particles and seasonal variations in urban and rural environment of Agra, India. Sci Total Environ 407:6196-6204. https://doi.org/10.1016/j.scitotenv.2009.08.050

43. Sharma SK, Mandal TK, Saxena M, Rashmi R, Sharma A, Gautam R (2014) Source apportionment of PM10 by using positive 
matrix factorization at an urban site of Delhi, India. Urban Clim 10:656-670. https://doi.org/10.1016/j.uclim.2013.11.002

44. Bilos C, Colombo JC, Skorupka CN, Rodrigues PMJ (2001) Sources, distribution and variability of airborne trace metal in La Plata City area, Argentina. Environ Pollut 111:149-158

45. Sharma R, Pervez S (2004) Chemical characterization and enrichment of selected toxic elements in ambient particulate matter around a slag based cement plant in Chhattisgarh state-a case study. J Sci Ind Res (India) 63:376-382

46. Querol X, Alastuey A, Rosa J, Sánchez-De-La-Campa A, Plana F, Ruiz CR (2002) Source apportionment analysis of atmospheric particulates in an industrialised urban site in southwestern Spain. Atmos Environ 36:3113-3125. https://doi.org/10.1016/ S1352-2310(02)00257-1

47. Mouli PC, Mohan SV, Balaram V, Kumar MP, Reddy SJ (2006) A study on trace elemental composition of atmospheric aerosols at a semi-arid urban site using ICP-MS technique. Atmos Environ 40:136-146. https://doi.org/10.1016/j.atmosenv.2005.09.028

48. Prabhu V, Shridhar V, Choudhary A (2019) Investigation of the source, morphology, and trace elements associated with atmospheric-PM10 and human health risks due to inhalation of carcinogenic elements at Dehradun, an Indo-Himalayan city. SN Appl Sci 1:429. https://doi.org/10.1007/s42452-019-0460-1

49. Galindo N, Yubero E, Nicolás JF, Varea M, Clemente A (2018) Daynight variability of PM10 components at a Mediterranean urban site during winter. Air Qual Atmos Health 11:1251-1258. https ://doi.org/10.1007/s11869-018-0627-8

50. Talbi A, Kerchich Y, Kerbachi R, Boughedaoui M (2018) Assessment of annual air pollution levels with PM1, PM2.5, PM10 and associated heavy metals in Algiers, Algeria. Environ Pollut 232:252-263. https://doi.org/10.1016/j.envpol.2017.09.041

51. Shakya KM, Peltier RE, Shrestha H, Byanju RM (2017) Measurements of TSP, PM10, PM2.5, BC, and PM chemical composition from an urban residential location in Nepal. Atmos Pollut Res 8:1123-1131. https://doi.org/10.1016/j.apr.2017.05.002

52. Das R, Khezri B, Srivastava B, Datta S, Sikdar PK, Webster RD, Wang X (2015) Trace element composition of PM2.5 and PM10 from Kolkata-a heavily polluted Indian metropolis. Atmos Pollut Res 6:742-750. https://doi.org/10.5094/apr.2015.083

53. Shridhar V, Khillare PS, Agarwal T, Ray S (2010) Metallic species in ambient particulate matter at rural and urban location of Delhi. J Hazard Mater 175:600-607. https://doi.org/10.1016/j.jhazm at.2009.10.047

54. Gummeneni S, Yusup YB, Chavali M, Samadi SZ (2011) Source apportionment of particulate matter in the ambient air of
Hyderabad city, India. Atmos Res 101:752-764. https://doi. org/10.1016/j.atmosres.2011.05.002

55. Jain S, Sharma SK, Choudhary N, Masiwal R, Saxena M, Sharma A, Mandal TK, Gupta A, Gupta NC, Sharma C (2017) Chemical characteristics and source apportionment of PM2.5 using PCA/ APCS, UNMIX, and PMF at an urban site of Delhi, India. Environ Sci Pollut Res 24:14637-14656. https://doi.org/10.1007/s1135 6-017-8925-5

56. Hsu CY, Chiang HC, Lin SL, Chen MJ, Lin TY, Chen YC (2016) Elemental characterization and source apportionment of PM10 and PM2.5 in the western coastal area of central Taiwan. Sci Total Environ 541:1139-1150. https://doi.org/10.1016/j.scito tenv.2015.09.122

57. Pandey M, Pandey AK, Mishra A, Tripathi BD (2017) Speciation of carcinogenic and non-carcinogenic metals in respirable suspended particulate matter (PM10) in Varanasi, India. Urban Clim 19:141-154. https://doi.org/10.1016/j.uclim.2017.01.004

58. Lee BK, Hieu NT (2011) Seasonal variation and sources of heavy metals in atmospheric aerosols in a residential area of Ulsan, Korea. Aerosol Air Qual Res 11:679-688. https://doi.org/10.4209/ aaqr.2010.10.0089

59. Kumar SS, Singh NA, Kumar V, Sunisha B, Preeti S, Deepali S, Nath SR (2008) Impact of dust emission on plant vegetation in the vicinity of cement plant. Environ Eng Manag J 7:31-35

60. Ramachandran $G$ (2018) Latest trends in civil engineering. Curr Trends Civ Struct Eng. https://doi.org/10.33552/ctcse .2018.01.000503

61. Shaik DS, Kant Y, Mitra D, Singh A, Chandola HC, Sateesh M, Babu SS, Chauhan $P$ (2019) Impact of biomass burning on regional aerosol optical properties: a case study over northern India. J Environ Manag 244:328-343. https://doi.org/10.1016/j.jenvm an.2019.04.025

62. Giglio L, Csiszar I, Justice CO (2006) Global distribution and seasonality of active fires as observed with the Terra and Aqua Moderate Resolution Imaging Spectroradiometer (MODIS) sensors. J Geophys Res Biogeosci 111:1-12. https://doi.org/10.1029/2005J G000142

Publisher's Note Springer Nature remains neutral with regard to jurisdictional claims in published maps and institutional affiliations. 